\title{
ANALISIS FAKTOR-FAKTOR PENYEBAB RENDAHNYA MOTIVASI BELAJAR SISWA MTS NEGERI 1 TAPANULI TENGAH DISAAAT PANDEMI COVID-19
}

\author{
Oleh: \\ Sri Wahyuni Naibaho'), Rahmatika Elindra' ${ }^{2)}$, Eva Yanti Siregar ${ }^{3)}$ \\ Fakultas MIPA, Institut Pendidikan Tapanuli Selatan
}

\begin{abstract}
Abstrak
Penelitian dilatarbelakangi karena saat ini dunia sedang dilanda pandemi Covid -19 yang menyebabkan beberapa negara melakukan lock down secara besar-besaran. Indonesia melaksanakan PSBB (Pembatasan Sosial Skala Besar - Besaran) di beberapa daerah dan melakukan pembelajaran di rumah. Pengaruh belajar di rumah adalah motivasi belajar rendah pada periode pandemi Covid-19. Tujuan penelitian ini adalah untuk mendeskripsikan faktor-faktor penyebab rendahnya motivasi belajar siswa periode pandemi Covid-19 di MTs Negeri 1 Tapanuli Tengah. Pendekatan penelitian menggunakan deskriptif kualitatif dan subjek penelitian adalah siswa kelas VII MTs Negeri 1 Tapanuli Tengah yang berjumlah 24 siswa. Kuisioner dan wawancara digunakan untuk mengumpulkan data. Hasil penelitian menunjukkan faktor-faktor penyebab rendahnya motivasi belajar siswa dalam pandemi Covid - 19 siswa di MTs Negeri 1 Tapanuli Tengah meliputi cita-cita atau aspirasi siswa, kemampuan siswa, kondisi siswa, kondisi lingkungan siswa, dan unsur dinamika dalam mengajar siswa. .
\end{abstract}

Kata kunci: motivasi belajar siswa, Covid-19

\begin{abstract}
The background of the study because at this time the world is troubled by the Covid-19 pandemic which has caused several countries to go into a massive lock down. Indonesia conducted PSBB (Large-Scale Social Restrictions) in several regions and conducted learning at home. The effect of learning at home is low learning motivation in pandemic Covid-19 period. The purpose of this study is to describe factors causing low motivation in pandemic Covid-19 period of students at MTs Negeri 1 Tapanuli Tengah. The approach of the research used qualitative descriptive and subject of the research is seventh grade students of MTs Negeri 1 Tapanuli Tengah which includes 24 students. Questionnaire and interview were used in collecting the data. The result of the research shows factors causing low learning motivation in pandemic Covid - 19 period of students at MTs Negeri 1 Tapanuli Tengah includes students' dream or aspiration, students' ability, students' condition, students' environment condition, and dynamic elements in teaching students.
\end{abstract}

\section{Keywords: students' learning motivation, Covid-19}

\section{PENDAHULUAN}

Pendidikan merupakan salah satu aspek penentu bagi kemajuan bangsa. Dengan pendidikan manusia dituntut untuk memporelah kepandaian dan ilmu, sehingga akan mampu menguasai bidang yang dipelajari sesuai tujuan dari pelaksanaan pendidikan. Keberhasilan dari proses pendidikan sangat dipengaruhi oleh pembelajaran yang berlangsung karena merupakan inti dari proses pendidikan. Pada dunia pendidikan keinginan/dorongan ketertarikan peserta didik dalam belajar merupakan salah satu kunci untuk mencapai keberhasilan dalam belajar. Pada saat ini, dunia kini diresahkan dengan adanya pandemi COVID-19 yang terjadi di beberapa wilayah membuat beberapa negara melakukan lock down secara besar-besaran karena sampai saat ini belum ditemukan obat maupun vaksinnya. Indonesia membuat PSBB (Pembatasan Sosial Berskala Besar) yang dilakukan disetiap daerah, kemudian melakukan pembelajaran daring atau online di rumah (BDR/Belajar dari rumah). Kegiatan pembelajaran dari rumah diberlakukan dari pendidikan dasar, pendidikan menengah bahkan pendidikan tinggi. Pada pendidikan menengah, siswa diminta untuk belajar dari rumah dalam mengikuti pembelajaran. Kesenjangan pembelajaran secara langsung dan secara online (BDR) membuat perubahan dalam kegiatan belajar siswa.

Berdasarkan hasil observasi awal penulis dengan ibu Nurhidayati Pinayungan pada tanggal 13 September 2020, bahwa motivasi belajar siswa rendah diakibatkan penutupan sekolah. Siswa dituntut untuk 
belajar dirumah, selain itu menurut ibu Nurhidayati bawa dalam belajar dirumah peserta didik sering mengalami kesulitan dalam belajar, tuga-tugas yang diberikan guru juga membuat anaknya tidak belajar karena tidak mampu menjawab pelajaran karena penjelasan dari guru hanya sedikit. Sehingga, anaknya lebih sering menghabiskan waktu untuk menonton televisi dan bermain handphone.

Tinggi rendahnya motivasi belajar peserta didik ini dapat menghambat perkembangan belajar dan merupakan ancaman bagi kemajuan belajar sehingga harus ditangani dengan tepat. Orang tua dan guru dituntut untuk dapat menanggulangi hal tersebut, seperti orang tua diharapkan dapat membantu dan memfasilitasi perlengkapan belajar peserta didik sehingga dapat menumbuhkan motivasi peserta didik dan guru saat membantu belajar peserta didik diharapkan mampu memberikan inovasi-inovasi yang menarik dan baru sehingga siswa memiliki motivasi belajar yang tinggi (Simanjuntak et al., 2020). Berdasarkan uraian diatas, peneliti tertarik melakukan penelitian berjudul: Analisis Faktor-Faktor Penyebab Rendahnya Motivasi Belajar Siswa Mts Negeri 1 Tapanuli Tengah Disaaat Pandemi Covid-19.

\section{HAKIKAT MOTIVASI BELAJAR}

Motivasi adalah semacam dorongan terhadap seseorang atau kelompok yang muncul dari diri seseorang atau kelompok atau juga bisa ditimbulkan faktor luar diri individu atau kelompok. Menurut M Utsman Najati dalam Ibnu (2012) "Motivasi adalah kekuatan penggerak yang membangkitkan aktivitas pada makhluk hidup, dan menimbulkan tingkah laku serta mengarahkannya menuju tujuan tertentu. Menurut Sudarwan dalam Suprihatin (2015:74) "Motivasi diartikan sebagai kekuatan, dorongan, kebutuhan, semangat, tekanan atau mekanisme psikologis yang mendorong seseorang atau sekelompok orang atau sekelompok orang untuk mencapai prestasi tertentu sesuai dengan apa yang dikehendaki”.

Belajar merupakan proses penting bagi perubahan perilaku manusia dan mencakup segala sesuatu yang dipikirkan dan dikejakan. Menurut Marleni dalam Tanjung dkk (2021:89) mengatakan "Belajar merupakan suatu proses yang dialami setiap individu yang menghasilkan perubahan, pemahaman, keterampilan dan sikap". Selanjutnya, menurut Skinner dalam Dimyati dan Mudjiono (2010:9) mengatakan "Belajar adalah perilaku". Pada saat orang belajar, maka responnya menjadi lebih baik. Berdasarkan beberapa pendapat diatas penulis menyimpulkan belajar adalah proses penting bagi perubahan perilaku manusia dan mencakup segala sesuatu yang difikirkan dan dikerjakan. Dalam belajar, siswa mengalami sendiri proses dari tidak tahu menjadi tahu.

Motivasi belajar merupakan syarat mutlak untuk belajar dan memegang peranan penting dalam memberikan gairah atau semangat dalam belajar. Menurut Clayton Alderfer dalam Hamdu dan Lisa Agustina (2011:83) mengatakan "Motivasi belajar adalah kecendrungan siswa dalam melakukan kegiatan belajar yang didorong oleh hasrat untuk mencapai prestasi atau hasil belajar sebaik mungkin". Menurut Sardiman dalam Kusuma dan Subkhan (2015:166) mengatakan "Motivasi belajar adalah dorongan dalam kegiatan bealajar, sehingga motivasi dapat dikatakan sebagai daya penggerak dalam diri siswa yang menimbulkan kegiatan belajar supaya tujuan yang dikehendaki oleh subjek belajar itu dapat dicapai". Berdasarkan beberapa pendapat diatas penulis menyimpulkan motivasi belajar merupakan dorongan proses belajar dengan kata lain tujuan dari belajar adalah mendapat hasil yang baik. Banyak siswa yang mengalami masalah dalam belajar akibatnya hasil belajar yang dicapai rendah. Rendahnya motivasi belajar siswa akan menghambat pencapaian tujuan pendidikan dan merupakan ancaman bagi kemajuan bangsa yang harus ditangani dengan tepat.

Faktor- faktor yang mempengaruhi motivasi belajar siswa menurut Dimyati dan Mudjiono (2009:97-99) antara lain:

a. Cita-Cita Siswa atau Aspirasi Siswa. Dari segi emansipasi kemandirian, keinginan yang terpuasakan dapat memperbesar kemauan dan semangat belajar.

b. Kemampuan Siswa. Keinginan seorang anak perlu dibarengi dengan kemauan atau kecakapan mencapainya.

c. Kondisi Siswa. Kondisi siswa meliputi kondisi jasmasi dan kondisi rohani mempengaruhi motivasi belajar.

d. Kondisi Lingkungan Siswa. Lingkungan siswa dapat berupa keadaan alam, lingkungan tempat tinggal, pergaulan sebaya, dan kehidupan masyarakat.

e. Unsur- Unsur Dinamis Dalam Belajar. Siswa memiliki perasaan, perhatian, kemauan, ingatan, dan pikiran yang mengalami perubahan berkat pengalaman hidup.

f. Upaya Guru Dalam Membelajarkan Siswa. Guru adalah seorang pendidik professional. ia bergaul setiap hari dengan puluhan atau ratusan siswa. Upaya guru membelajarkan siswa terjadi di sekolah maupun diluar sekolah.. 
Kemudian Ali Imron dalam Siregar dan Nara (2010:53-55) mengemukakan Faktor-faktor yang mempengaruhi motivasi yaitu:

a. Cita-cita/aspirasi pembelajar. Cita cita merupakan salah satu faktor yang mempengaruhi motivasi belajar.

b. Kemampuan Pembelajaran. Kemampuan pembelajaran juga menjadi faktor penting dalam mempengaruhi motivasi.

c. Kondisi Pembelajaran . Hal ini dapat terlihat dari kondisi fisik maupun kondisi psikis pembelajaran.

d. Kondisi Lingkungan. Dapat diamati dari lingkungan fisik dan lingkungan yang mengitari si pembelajar.

e. Unsur-unsur dinamis belajar/pembelajaran.Hal ini dapat diamati pada sejauh mana upaya memotivasi tersebut dilakukan.

f. Upaya Guru Dalam Membelajarkan Pembelajar

Menurut Slameto (2015:74-76) faktor yang mempengaruhi motivasi belajar siswa diantaranya

a. Kondisi Internal. Kondisi internal yaitu kondisi (situasi) yang ada didalam diri siswa itu sendiri misalnya kesehatannya, keamananya ketentramannya dan sebagainya.

b. Kondisi Eksternal. Kondisi eksternal adalah kondisi yang ada diluar pribadi manusia, misalnya kebersihan rumah, penerangan, serta keadaan lingkungan.

c. Stategi belajar. Belajar yang efisisen dapat tercapai apabila dapat menggunakan stategi yang tepat. Strategi belajar diperlukan untuk dapat mencapai hasil yang semaksimal mungkin.

Menurut Sudaryono dalam Moslem, dkk (2019:259-260) faktor-faktor yang mempengaruhi motivasi belajar siswa diantaranya.

a. Faktor Internal yaitu faktor yang bersumber dari dalam diri siswa seperti kondisi jasmani dan rohani, cita-cita atau aspirasi, kemampuan siswa dan perhatian.

b. Faktor Eksternal yaitu faktor yang bersumber dari luar diri siswa seperti kondisi lingkungan siswa, unsur-unsur dinamis dalam belajar dan upaya guru dalam mengelola kelas.

Berdasarkan beberapa pendapat diatas maka penulis menyimpulkan bahwa faktor-faktor yang mempengaruhi motivasi belajar siswa yaitu:

a. Cita-Cita Atau Aspirasi.

b. Kondisi Siswa.

c. Kemampuan Siswa

d. Kondisi Lingkungan Siswa.

e. Unsur- Unsur Dinamis Dalam Belajar.

f. Upaya Guru Dalam Membelajarkan Siswa.

Matematika memiliki peranan penting dalam segala aspek kehidupan terutama dalam meningkatkan daya pikir manusia. Matematika berasal dari bahasa Latin mathanein atau mathema yang berarti belajar atau hal yang sedang dipelajari, sedang dalam bahasa Belanda disebut wiskunde atau ilmu pasti. Menurut Suthawidjaja dan Dahlan dalam Siagian (2017:63) mengatakan "matematika itu memiliki sifat aksioma yaitu bahwa suatu struktur matematika dimulai dari istilah yang tidak ditemukan (undefined term) atau istilah pangkal dan kaidah yang berkaitan dengan istilah pangkat tersebut yang disepakati kebenarannya yang disebut aksioma". Russefendi dalam Apriadi dkk (2021:135) "Matematika lebih menekankan kegiatan dalam dunia rasio (penalaran), bukan menekankan dari hasil eksperimen atau hasil observasi matematika terbentuk karena pikiran-pikiran manusia, yang berhubungan dengan ide, proses dan penalaran" ..Berdasarkan beberapa pendapat maka penulis menyimpulkan matematika adalah ilmu tentang logika mengenai bentuk, susunan, besaran dan konsep-konsep yamg saling berkaitan.

\section{Hakekat Pandemi COVID-19}

Pada akhir 2019 dunia dikejutkan dengan munculnya suatu penyakit yang disebabkan oleh virus. Virus tersebut ramai diberitakan muncul dari suatu Pasar Grosir Makanan Laut Huanan yang ada di Kota Wuhan, Ibu kota Provinsi Hubei, Cina Tengah. Wuhan sendiri termasuk kota megapolitan dengan total penduduk mencapai belasan juta warga, sama seperti Beijing, Shanghai, dan lain-lain. Untuk nama penyakit digunakan istilah COVID-19 yang diresmikan oleh WHO (World Health Organization) pada tanggal 11 Februari 2020. COVID-19 atau "The COVID19 virus" merupakan singkatan dari Coronavirus Disease 2019. COVID-19 adalah penyakit menular yang mirip dengan influenza yang disebabkan oleh Severe Acute Respiratory Syndrome Coronavirus 2 (SARS-CoV-2) (Gorbalenya et al., 2020; Lin et al., 2020). 


\section{METODE PENELITIAN}

Metode penelitian merupakan suatu cara yang digunakan dalam penelitian untuk mengumpulkan data penelitian. Sugiyono (2018:3) mengatakan "Metode penelitian pada dasarnya merupakan cara ilmiah untuk mendapatkan data dengan tujuan dan kegunaan tertentu". Menurut Miles dan Huberman dalam Ahmad (2014:18) menyebutkan "Metode kualitatif berusaha mengungkap berbagai keunikan yang terdapat dalam individu, kelompok, masyarakat, atau organisasi dalam kehidupan sehari-hari secara menyeluruh, rinci, dalam, dan dapat dipertanggungjawabkan secara ilmiah". Menurut Sugiyono (2018:15) berpendapat "Metode penelitian kualitatif adalah metode penelitian yang berlandaskan pada filsafat postpositivisme, digunakan untuk meneliti pada kondisi obyek yang alamiah, (sebagai lawannya adalah eksperimen) dimana peneliti adalah sebagai instrumen kunci, pengambilan sampel sebagai sumber data dilakukan secara purposive dan snowbaal, teknik pengumpulan data (gabungan), analisis data bersifat induktif/kualitatif, dan hasil penelitian kualitatif lebih menekankan makna dari pada generalisasi. Dalam penelitian ini penulis menggunakan penelitian deskriptif. Penelitian Deskriptif adalah penelitian yang dilakukan untuk mengetahui nilai variabel bebas, baik satu variabel atau lebih (independent) tanpa membuat perbandingan, atau menghubungkan variabel yang satu dengan yang lain.

\section{Objek dan Informan Penelitian}

Adapun objek dalam penelitian ini analisis faktor-faktor rendahnya motivasi belajar siswa MTs Negeri 1 Tapanuli Tengah disaat pandemi Covid-19. Informan dalam penelitian ini adalah siswa dan guru MTs Negeri 1 Tapanuli Tengah. Data adalah segala fakta dan angka yang dapat dijadikan bahan untuk menyusun suatu informasi, data yang diperoleh nantinya diolah sehingga menjadi informasi yang lebih baru. sumber data primer dalam penelitian ini adalah siswa itu sendiri, Sedangkan, sumber data primer yang diperoleh baik dari buku pendidikan dan jurnal pendidikan.

\section{Teknik Pengumpulan Data}

Menggunakan wawancara dan angket. Wawancara digunakan sebagai teknik pengumpulan data apabila peneliti ingin melakukan studi pendahuluan untuk menemukan permasalahan yang harus diteliti, dan juga apabila peneliti ingin mengetahui hal-hal dari respon yang lebih mendalam dan jumlah respondennya sedikit/kecil. Angket (Kuesioner)Kuesioner dapat berupa pertanyaan/pernyataan tertutup atau terbuka, dapat diberikan kepada responden secara langsung atau dikirim melalui pos, atau internet. Menurut Sugiyono (2018:199) mengatakan "Angket (kuesioner) merupakan teknik pengumpulan data dengan cara memberi seperangkat pertanyaan atau pernyataan tertulis kepada responden untuk dijawabnya".

Tabel 1

Kisi Kisi Faktor-Faktor Penyebab Rendahnya Motivasi Siswa Mts Negeri 1 Tapanuli Tengah Disaat Pandemi COVID-19

\begin{tabular}{llcc} 
No & \multicolumn{1}{c}{ Indikator } & $\begin{array}{c}\text { Item } \\
\text { Pernyataan }\end{array}$ & $\begin{array}{c}\text { Banyak } \\
\text { pernyataan }\end{array}$ \\
\hline 1 & Cita-cita/Aspirasi Siswa & $1,2,3$ & 3 \\
\hline 2 & Kemampuan siswa & $4,5,6$ & 3 \\
\hline 3 & Kondisi Siswa & 7,8 & 2 \\
\hline 4 & Kondisi Lingkungan & 9,10 & 2 \\
\hline 5 & $\begin{array}{l}\text { Unsur-unsur dinamis dalam } \\
\text { belajar }\end{array}$ & $11,12,13$ & 3 \\
\hline 6 & $\begin{array}{l}\text { Upaya guru dalam } \\
\text { membelajarkan siswa }\end{array}$ & 14,15 & 2 \\
\hline
\end{tabular}

\section{JUMLAH} 15

Berbagai skala sikap yang dapat digunakan untuk penelitian pendidikan, menurut Sugiyono (2014:132-139), yaitu:

1. Skala likert digunakan untuk mengukur sikap, pendapat, dan persepsi seseorang atau sekelompok orang tentang fenomena sosial, yaitu "sangat baik", "baik", "cukup", "kurang", "sangat kurang".

2. Skala Guttman yaitu skala pengukuran yang akan mendapat jawaban yang tegas, yaitu "ya-tidak", "benar-salah", "pernah-tidak pernah", "positif-negatif", dan lain-lain.

3. Semantic Defferensial digunakan untuk mengukur sikap, hanya untuk pilihan ganda maupun cheklist, tetapi tersusun dalam satu garis kontinum. 
4. Rating Scale yaitu data mentah yang diperoleh berupa angka kemudian ditafsirkan dalam pengertian kualitatif.

Peneliti menggunakan skala Guttman dalam penelitian ini, yaitu dengan jawaban "Ya" dan "Tidak", dengan perhitungan $\mathrm{Ya}=1$, Tidak $=0$. Instrumen penelitian yang menggunakan skala guttman dapat dibuat dalam bentuk cheklis.

$$
\text { Nilai akhir }=\frac{\text { Jumlah Skor yang dipeoleh }}{\text { jumlah Skor Maksimal }} \text { X } 100
$$

Tabel 3

\section{Kriteria Penilaian Angket Motivasi Belajar Siswa} Nilai Kriteria

\begin{tabular}{cc}
\hline $0-20,99$ & Tidak Termotivasi \\
\hline $21-40,99$ & Kurang Termotivasi \\
\hline $41-60,99$ & Cukup Termotivasi \\
\hline $61-80,99$ & Termotivasi \\
\hline $81-100$ & Sangat Termotivasi
\end{tabular}

Untuk mengukur tingkat kepercayaan (kredibilitas) penelitian kualitatif sehingga dapat dipertanggunjawabkan secara ilmiah. Pengukuran keabsahan data pada penelitian ini dilakukan dengan triangulasi.

\section{Teknik Analisis Data}

Reduksi Data

Reduksi data merupakan proses berpikir sensitif yang memerlukan kecerdasan dan keluasan dan kedalaman wawasan yang tinggi. Ahmad (2014:156) mengatakan "Mereduksi data berarti merangkum, memilih hal-hal yang pokok, memfokuskan pada hal-hal yang penting, dicari tema dan polanya dan membuang yang tidak perlu".

Penyajian Data

Data display didefinisikan juga sebagai data organized, suatu cara pengkompresan informasi yang memungkinkan suatu kesimpulan atau tindakan diambil sebagai bagian dari analisis". Miles dan Huberman (2002) dalam Ahmad (2014:157) mengatakan "Dengan mendisplaykan data, maka akan memudahkan untuk memahami apa yang terjadi, merencanakan kerja selanjutnya berdasarkan apa yang telah dipahami tersebut". Silalahi (2012:340) mengatakan "Penyajian data adalah sekumpulan data informasi tersusun yang memberi kemungkinan adanya penarikan kesimpulan dan pengambilan tindakan”.

Kesimpulan dan Verifikasi Data

Menurut Sugiyono (2018:345) mengatakan "Kesimpulan dalam penelitian kualitatif yang diharapkan adalah temuan baru yang sebelumnya belum pernah ada. Temuan dapat berupa deskripsi atau gambaran obyek yang sebelumnya masih reman-remang atau gelap sehinga setelah diteliti menjad jelas". Ahmad (2014:158) mengatakan "Kesimpulan dan verifikasi data merupakan tindaan penelitian dalam menginterpretasikan data, menggambarkan makna dari data display".

\section{HASIL DAN PEMBAHASAN}

Temuan Umun

MTs N 1 Tapanuli Tengah terletak di jln. Syehrukunuddin desa Kampung Mudik kecamatan Barus kabupaten Tapanuli Tengah Provinsi Sumatera Utara. Desa kampung mudik berjarak $\pm 2.5 \mathrm{~km}$ dari pusat kecamatan dan $\pm 80 \mathrm{~km}$ dari pusat kabupaten Tapanuli Tengah. Tata tempat tinggal dan sanitasi didesa kampong mudik cukup baik dengan sarana dan prasarana yang cukup memadai mulai dari masjid, musholla, perpustakaan, laboratorium komputer, dan sarana prasarana umum lainnya, sehingga menjadikan MTsN 1 Tapanuli Tengah menjadi salah satu madrasah unggulan di Tapanuli Tengah. Ruang kelas berjumlah 17 kelas yang terdiri dari 5 ruangan kelas VII, 5 ruangan kelas VIII, dan 7 ruangan kelas IX. MTsN 1 Tapanuli Tengah dipimpin oleh ibu Elmaryanti Marbun, S.Ag, M.Hum.

\section{Temuan Khusus}

Hasil angket yang dibagikan kepada siswa MTs N 1 Tapanuli Tengah kelas vii b sebanyak 24 siswa. Setelah peneliti membagikan angket kepada siswa dengan 15 item pernyataan, maka peneliti mengambil perwakilan dari 24 siswa untuk dijabarkan yaitu siswa yang berkategori "kurang termotivasi", "cukup termotivasi", "termotivasi" dan "sangat termotivasi". Angket yang dibagikan siswa hanya menceklis 
ISSN. 2621-9832

JURNAL MathEdu (Mathematic Education Journal) http://journal.ipts.ac.id/index.php/MathEdu Vol. 4 No. 2 Juli 2021

jawaban "Ya" dan "Tidak". Setelah pemberian angket kemudian dilakukan wawancara dengan 4 orang siswa, dan guru matemetika.

\section{Hasil Jawaban Angket}

Berikut hasil jawaban angket responden yang dilakukan oleh siswa MTs Negeri 1 Tapanuli tengah kelas VII-b yang berjumlah 24 siswa. Pada tanggal 03 Maret 2021

Tabel 4

Kriteria Penilaian Angket Faktor-Faktor Penyebab Rendahnya Motivasi Belajar Siswa MTs Negeri 1 Tapanuli Tengah Disaat Pandemi COVID-19

\begin{tabular}{|c|c|c|c|c|c|c|c|}
\hline \multirow[b]{2}{*}{ No } & \multirow[b]{2}{*}{$\begin{array}{l}\text { Nama } \\
\text { siswa }\end{array}$} & \multirow[b]{2}{*}{$\mathbf{J b} / \mathbf{N} \times 100$} & \multicolumn{5}{|c|}{ Kriteria Penilaian } \\
\hline & & & $\begin{array}{c}0- \\
20,99 \\
(\mathrm{TT})\end{array}$ & $\begin{array}{c}21- \\
40,99 \\
(\text { KT) }\end{array}$ & $\begin{array}{c}41- \\
60,99 \\
(\mathrm{CT})\end{array}$ & $\begin{array}{c}61- \\
80,99 \\
(\mathrm{~T})\end{array}$ & $\begin{array}{c}81-100 \\
(\mathrm{ST})\end{array}$ \\
\hline 1 & RM & $6 / 15 \times 100=40$ & & $\checkmark$ & & & \\
\hline 2 & DMS & $9 / 15 \times 100=60$ & & & $\checkmark$ & & \\
\hline 3 & SIM & $11 / 15 \times 100=73,3$ & & & & $\checkmark$ & \\
\hline 4 & KG & $7 / 15 \times 100=45,67$ & & & $\checkmark$ & & \\
\hline 5 & SJS & $8 / 15 \times 100=53,3$ & & & $\checkmark$ & & \\
\hline 6 & MAS & $6 / 15 \times 100=40$ & & $\checkmark$ & & & \\
\hline 7 & $\mathrm{HS}$ & $7 / 15 \times 100=46,67$ & & & $\checkmark$ & & \\
\hline 8 & NAS & $14 / 15 \times 100=93,3$ & & & & & $\checkmark$ \\
\hline 9 & RAT & $7 / 15 \times 100=46,67$ & & & $\checkmark$ & & \\
\hline 10 & FA & $8 / 15 \times 100=53,33$ & & & $\checkmark$ & & \\
\hline 11 & AS & $11 / 15 \times 100=73,3$ & & & & $\checkmark$ & \\
\hline 12 & SMP & $7 / 15 \times 100=46,67$ & & & $\checkmark$ & & \\
\hline 13 & WT & $7 / 15 \times 100=46,67$ & & & $\checkmark$ & & \\
\hline 14 & SR & $9 / 15 \times 100=60$ & & & $\checkmark$ & & \\
\hline 15 & DAS & $5 / 15 \times 100=33,3$ & & $\checkmark$ & & & \\
\hline 16 & SR & $11 / 15 \times 100=73,3$ & & & & $\checkmark$ & \\
\hline 17 & DRS & $9 / 15 \times 100=60$ & & & $\checkmark$ & & \\
\hline 18 & SR & $11 / 15 \times 100=73,3$ & & & & $\checkmark$ & \\
\hline 19 & RR & $10 / 15 \times 100=66,67$ & & & & $\checkmark$ & \\
\hline 20 & RAS & $10 / 15 \times 100=66,67$ & & & & $\checkmark$ & \\
\hline 21 & NAR & $5 / 15 \times 100=33,3$ & & $\checkmark$ & & & \\
\hline 22 & LRT & $5 / 15 \times 100=33,3$ & & $\checkmark$ & & & \\
\hline 23 & RUS & $7 / 15 \times 100=46,67$ & & & $\checkmark$ & & \\
\hline 24 & JNS & $6 / 15 \times 100=40$ & & $\checkmark$ & & & \\
\hline
\end{tabular}

Tabel 5

Hasil Jawaban Angket Faktor-Faktor Penyebab Rendahnya Motivasi Belajar Siswa MTs Negeri 1 Tapanuli Tengah Disaat Pandemi COVID-19

\begin{tabular}{|c|c|c|c|c|c|c|}
\hline \multirow[b]{2}{*}{ No } & \multirow[b]{2}{*}{$\begin{array}{l}\text { Nama } \\
\text { siswa }\end{array}$} & \multicolumn{5}{|c|}{ Kriteria Penilaian } \\
\hline & & $\begin{array}{r}0-20,99 \\
(T T)\end{array}$ & $\begin{array}{c}21-40,99 \\
\text { (KT) }\end{array}$ & $\begin{array}{c}\text { 41-60,99 } \\
\text { (CT) }\end{array}$ & $\begin{array}{c}\text { 61-80,99 } \\
\text { (T) }\end{array}$ & $\begin{array}{c}\text { 81-100 } \\
\text { (ST) }\end{array}$ \\
\hline 1 & RM & & $\checkmark$ & & & \\
\hline 2 & DMS & & & $\checkmark$ & & \\
\hline 3 & SIM & & & & $\checkmark$ & \\
\hline 4 & $\mathrm{KG}$ & & & $\checkmark$ & & \\
\hline 5 & SJS & & & $\checkmark$ & & \\
\hline 6 & MAS & & $\checkmark$ & & & \\
\hline 7 & $\mathrm{HS}$ & & & $\checkmark$ & & \\
\hline 8 & NAS & & & & & $\checkmark$ \\
\hline 9 & RAT & & & $\checkmark$ & & \\
\hline 10 & FA & & & $\checkmark$ & & \\
\hline
\end{tabular}




\begin{tabular}{lcccc}
\hline 11 & AS & & & $\checkmark$ \\
\hline 12 & SMP & & $\checkmark$ & \\
\hline 13 & WT & & $\checkmark$ & \\
\hline 14 & SR & $\checkmark$ & & \\
\hline 15 & DAS & & & $\checkmark$ \\
\hline 16 & SR & & $\checkmark$ & $\checkmark$ \\
\hline 17 & DRS & & & $\checkmark$ \\
\hline 18 & SR & & & \\
\hline 19 & RR & $\checkmark$ & & \\
\hline 20 & RAS & $\checkmark$ & & \\
\hline 21 & NAR & LRT & & \\
\hline 23 & RUS & $\checkmark$ & & \\
\hline 24 & JNS & & & \\
\hline
\end{tabular}

Table 6

Hasil Jawaban Yang Diperoleh Dari Penyebaran Angket Tentang Motivasi Belajar Siswa MTs Negeri 1 Tapanuli Tengah Disaat Pandemi COVID-19

\begin{tabular}{ccccc}
\hline No & Skor & Kategori & $\begin{array}{c}\text { Jumlah } \\
\text { Informan }\end{array}$ & Jb/N x 100 \\
\hline 1 & $0-20,99$ & Tidak Termotivasi & 0 & 0 \\
\hline 2 & $21-40,99$ & Kurang Termotivasi & 6 & 25 \\
\hline 3 & $41-60,99$ & Cukup Termotivasi & 12 & 50 \\
\hline 4 & $61-80,99$ & Termotivasi & 5 & 20,8 \\
\hline 5 & $81-100$ & Sangat Termotivasi & 1 & 4,2 \\
\hline & Jumlah & & $\mathbf{2 4}$ & $\mathbf{1 0 0}$ \\
\hline
\end{tabular}

Berdasarkan dari hasil tabel jawaban yang diperoleh dari penyebaran angket faktor-faktor yang mempengaruhi motivasi belajar siswa di MTs Negeri 1 Tapanuli Tengah disaat pandemi covid-19 yaitu pada kategori tidak termotivasi menjawab 0. Kategori kurang termotivasi menjawab sebanyak 6 orang atau 25 masuk dalam kategori kurang berminat disebabkan faktor internal yaitu cita-cita/aspirasi siswa dimana siswa tidak bersungguh-sungguh mengerjakan tugas, siswa kurang yakin akan jawabannya, siswa tidak lansung mengerjakan tugas, faktor kemampuan siswa dimana siswa tidak tertarik dengan pelajara matematika, siswa tidak memiliki potensi (kemampuan) dibidang matematika, dan siswa kesulitan dalam memahami tugas matematika, faktor kondisi lingkungan dimana siswa merasa bosan dalam belajar, dan kurang bersemangat dalam belajar, dan faktor eksternal yaitu faktor kondisi lingkungan dimana pada saat mengalami kesulitan siswa tidak dibantu dalam belajar dan televisi mereka menyala pada saat belajar dirumah, faktor unsur-unsur dinamis dalam belajar dimana fasilitas belajar siswa kurang memadai, dan mereka tidak mengikuti bimbel selain dari sekolah. Kategori cukup termotivasi menjawab sebanyak 12 orang atau 50 disebabkan faktoi internal yaitu faktor cita/cita aspirasi siswa dimana siswa tidak yakin akan jawaban siswa, siswa juga tidak yakin akan jawabannya, siswa tidak lamgsung mejawab soal, faktor kemampuan siswa dimana siswa tidak memiliki potensi (kemampuan) dalam bidang pelajaran matematika, siswa kesulitan dalam memahami tugas-tugas matematika, dan faktor kondisi siswa dimana siswa merasa bosan dan kurang bersemangat dalam belajar, dan faktor eksternal yaitu faktor kondisi lingkungan dimana pada saat belajar matematika dirumah televisi menyala dan faktor unsur-unsur dinamis dalam belajar dimana fasilitas belajar kurang lengkap dan siswa tidak mengikuti bimbel selain dari guru disekolah masuk dalam kategori cukup termotivasi. Kategori termotivasi menjawab sebanyak 5 orang atau 20,8 disebabkan faktor internal yaitu faktor cita-cita/aspirasi siswa dimana siswa kurang yakin akan jawabannya, faktor kondisi siswa dimana siswa merasa bosan dalam belajar matematika dan faktor eksternal yaitu faktor unsurunsur dinamis dalam belajar dimana siswa tidak mengikuti bimbel selain dari guru disekolah, masuk dalam kategori termotivasi. Dan kategori sangat termotivasi menjawab 1 atau 4,2 dimana disebabkan faktor kondisi siswa dimana siswa merasa bosan belajar dirumah selama pandemi covid-19, masuk dalam kategori sangat termotivasi. Dengan demikian dapat disimpulkan bahwa motivasi belajar siswa disaat pandemi covid-19 di MTs Negeri 1 Tapanuli Tengah masuk dalam kategori cukup termotivasi. 


\section{Kesimpulan}

Gambaran dari hasil penelitian yang dilakukan dapat disimpulkan bahwa faktor-faktor yang mempengaruhi motivasi belajar siswa di MTs Negeri 1 Tapanuli Tengah disaat pandemi covid-19 yaitu pada kategori tidak termotivasi menjawab 0. Kategori kurang termotivasi menjawab sebanyak 6 orang atau 25\% masuk dalam kategori kurang. Kategori cukup termotivasi menjawab sebanyak 12 orang atau $50 \%$ masuk dalam kategori cukup termotivasi. Kategori termotivasi menjawab sebanyak 5 orang atau 20,8\% masuk dalam kategori termotivasi. Dan kategori sangat termotivasi menjawab 1 orang atau 4,2\% masuk dalam kategori sangat termotivasi. Jadi faktor-faktor yang mempengaruhi motivasi belajar siswa di MTs Negeri 1 Tapanuli Tengah disaat pandemi covid-19 yaitu 1) Cita-cita/aspirasi siswa, 2) Kemampuan siswa, 3) Kondisi siswa, 4) Kondisi lingkungan siswa dan 5) Unsur-unsur dinamis dalam membelajarkan siswa.

\section{Implikasi}

Implikasi merupakan arah dan tindak lanjut dari makna yang terkandung dalam temuan penelitian. Dengan demikian penelitian ini memiliki implikasi terdapat motivasi belajar siswa MTs Negeri 1 Tapanuli Tengah disaat pandemi covid-19 masuk dalam kategori cukup termotivasi, oleh karena itu agar kedepannya siswa lebih memfokuskan dan lebih meningkatkan motivasi belajarnya, apabila mengalami kesulitan dan merasa bosan atau jenuh dalam belajar ada baiknya bertanya kepada teman atau orang yang lebih ahli dalam bidang itu,siswa diharapkan melengkapi fasilitas belajar selama pandemi covid-19, siswa juga diharapkan mengikuti bimbel selain dari sekolah.

\section{Saran}

Berdasarkan kesimpulan dan implikasi hasil penelitian yang telah dikemukakan diatas, maka peneliti menyarankan hal-hal sebagai berikut:

1. Bagi siswa agar lebih meningkatkan motivasi belajar pada masa pandemi covid-19 ada baiknya bertanya kepada teman atau orang tua apabila mengalami kesulitan dalam belajar.

2. Bagi orang tua sebagai masukan agar lebih bisa membagi waktu dalam mendampingi anak belajar dirumah, dan tetap memeriksa apakah anak benar-benar belajar dirumah.

3. Bagi peneliti lain sebagai bahan masukan dalam membuat karya ilmiah yang lebih baik lagi

\section{DAFTAR PUSTAKA}

Abdillah, Leon A. 2020. Stigma Terhadap Orang Positif COVID-19. http://eprints.binadarma.ac.id/4163/. Diaksespada bulan juni 2020.

Apriadi, Muhammad Akbar.,Elindra, Rahmatika \& Harahap, Muhammad syahril. 2021. Analisis Kemampuan Pemecahan Masalah Matematis Siswa Sebelum Dan Sesudah Masa Pandemi Covid-19. JURNAL MathEdu (Mathematic Education Journal). Volume IV; 133-144

Dimiyati. Mudjiono. 2009. Belajar Dan Pembelajaran. Jakarta: Rineka Cipta.

Fitriyani, Yani., Fauzi, Irfan \& Sari, Mia Zultrianti. 2020. Motivasi Belajar Mahasiswa Pada Pembelajaran Daring Selama Pandemi Covid 19. Jurnal Kependidikan: Jurnal Hasil Penelitian Dan Kajian Kepustakaan Di Bidang Pendidikan, Pengajaran Dan Pembelajaran. Volume VI Tahun 2020; 165-175.

Hamdu, Ghullam dan Agustina, Lisa. 2011. Pengaruh Motivasi Belajar Siswa Terhadap Prestasi Belajar IPA Di Sekolah Dasar. Jurnal Penelitilian Pendidikan. Volume XII Tahun 2020.

Kusuma, Zuhaira Laily dan Subkhan. 2015. Pengaruh Motivasi Belajar Dan Kedisiplinan Belajar Terhadap Prestasi Belajar Mata Pelajaran Akuntansi Siswa Kelas XI IPS SMA N 3 Pati Tahun Pelajaran 2013/2014. Economic Education Analysis Journal. Volume IV Tahun 2020.

Mahmudi, Ibnu. 2012. Peningkatan Motivasi Belajar Melalui Bimbingan Konseling Islam. Jurnal Bimbingan dan Konseling. Volume I Tahun 2020.

Moslem dkk. 2019. Faktor-Faktor Yang Menyebabkan Rendahnya Motivasi Belajar Siswa Dalam Mata Pelajaran Aircraft Drawing Di SMK. Journal of Mechanical Eingineering Education. Volume VI Tahun 2020.

Pakpahan, Roida dan Fitriani, Yuni. 2020. Analisa Pemanfaatan Teknologi Informasi Dalam Pembelajaran Jarak Jauh Di Tengah Pandemi Virus Corona Covid-19. Journal Of Informatian System, Applied, Management, Accounting And Research (JISAMAR). Volume IV Tahun 2020.

Rangkuti, Ahmad Nizar. 2014. Metode Penelitian Pendidikan Pendekatan Kuantitaf, Kualitatif, PTK, dan Penelitian Pengembangan. Bandung: Citapustaka media. 
Sabrina, Ridha,. Fauzi \& Yamin, M dkk. 2017. Faktor-Faktor Penyebab Rendahnya Motivasi Belajar Siswa Dalam Proses Pembelajaran Matematika Di Kelas V SD Negeri Garot Geu Ceu Aceh Besar. Jurnal Ilmiah Pendidikan Guru Sekolah Dasar FKIP Unsyiah. Volume II Tahun 2020; 108-118.

Siagian, Muhammad Daud. 2017. Pembelajaran Matematika Dalam Perspektif Kontruktivisme. HIZMIYAH Jurnal Pendidikan Islam dan Teknologi Pendidikan. Volume II Tahun 2020 (61-73) Silalahi Ulber. 2012. Metode Penelitian Sosial. Bandung: Pt Refika Aditama.

Simanjuntak, D. R., Ritonga, M. N., \& Harahap, M. S. (2020). ANALISIS KESULITAN BELAJAR SISWA MELAKSANAKAN PEMBELAJARAN SECARA DARING SELAMA MASA PANDEMI COVID-19 Oleh. Mathematic Education Journal)MathEdu, 3(3), 142-146. http://journal.ipts.ac.id/index.php/

Slameto. 2015. Belajar Dan Fakttor-Faktor Yang Mempengaruhinya. Jakarta: Rineka Cipta.

Sugiyono. 2014. Metode Penelitian Bisnis (Pendekatan Kuantitatif, Kualitatif, dan R\&D). Bandung: Alfabeta.

Sugiyono. 2018. Metode Penelitian Pendidikan Pendekatan Kuantitatif, Kualitatif, dan R\&D. Bandung: Alfabeta.

Sukmadinata, Nana Syaodih. 2010. Metode Penalitian Pendidikan. Bandung: Pt Ramaja Rosdakarya.

Suprihatin, Siti. 2015. Upaya Guru Meningkatkan Motivasi Belajar Siswa. Jurnal Pendidikan Ekonomi UM Metro. Volume III Tahun 2020 (73-82).

Tanjung, Rapita., Ritonga, Tamin., \& Siregar, Eva Yanti. 2021. Analisis Minat Belajar Siswa Dalam Pembelajaran Daring Pada Masa Pandemi Covid-19 Di Desa Ujung Batu Barus. JURNAL MathEdu (Mathematic Education Journal). Volume IV; 88-96.

Yunus, Nur Rohman dan Rezki Annisa. 2020. Kebijakan Pemberlakuan Lockdown Sebagai Antisipasi Penyebaran Coronavirus Covid-19. Salam: Jurnal Sosial \& Budaya Syar-i. Volume VII Tahun 2020 (227-238). 